\title{
Reproductive phenology of Uspí tree Couepia polyandra (Kunth) Rose (Chrysobalanaceae) in Campeche, Mexico
}

\author{
Mejenes-López, Sol de Mayo A. ${ }^{1}$; Mendoza-Arroyo Gustavo E. ${ }^{1}$; Marín-Quintero, Manuel ${ }^{2}$; Chiquini-Medina, Ricardo A. ${ }^{2 *}$ \\ ${ }^{1}$ Departamento de Ciencias Básicas, Instituto Tecnológico de Chiná, ITChiná, TecNM. ²Departa- \\ mento de Ingenierías, Instituto Tecnológico de Chiná, ITChiná, TecNM. \\ *Autor para la correspondencia: ricardochiquini@yahoo.com.mx
}

\section{ABSTRACT}

Objective. To describe reproductive phenological stages, since the formation of flower buds, flowering, fruiting, up to the formation of the ripe fruit and foliation of 21 Couepia polyandra trees; and correlation of allometric data of tree height, diameter at breast height $(\mathrm{DBH})$ and crown diameter, as well as the correlation of precipitation with reproductive phenology data.

Methodology. The description of the reproductive phenology (foliage, formation of flower buds, flowers, fruits) was done by direct monthly observation with a digital camera (Canon SX60HS, 65). The correlation among precipitation, allometry, and types of soils where the trees grow was calculated by recording data from each tree by measuring height, diameter at breast height $(\mathrm{DBH})$ and foliage.

Results. The highest tree was $21.0 \mathrm{~m}$; the widest DBH measured $68 \mathrm{~cm}$; and the greater crown diameter was $34.45 \mathrm{~m}$; the overall averages were $10.38 \mathrm{~m}, 33.17 \mathrm{~cm}$ and $9.37 \mathrm{~m}$, respectively. A significant correlation was found between height and DBH $(r=0.91, p<0.05)$; the correlations for the variables Height-Crown and DBH-Crown were not significant $(p>0.05)$.

Conclusions. Water as a factor is responsible for the formation of inflorescence and fruit; determining that these phenological events are dependent variables with precipitation, highlighting a mean positive relation with the growth of flowers.

Keywords: Uspi, southeast, backyard orchards, flowering, fruiting, precipitation.

\section{INTRODUCTION}

Despite

the importance of phenological knowledge of tree species, to date in Mexico only those species with the highest commercial value have been studied in detail (Salinas-Peba $\&$ Parra-Tabla, 2007) and dry forests are not the exception (Porter-Bolland, 2003) from the Yucatán Peninsula in southeastern Mexico. Authors such as Valdez et al. (2010) point out differences in the phenology of tree species between subsequent years, and suggest that rains occurrence, as well as the duration of periods without rain, may play a more important role in phenology than the total annual precipitation. Differences among sites suggest a strong effect on the phenology of trees, and finally Rozendal and Zuidema (2011) confirm that these specific responses of

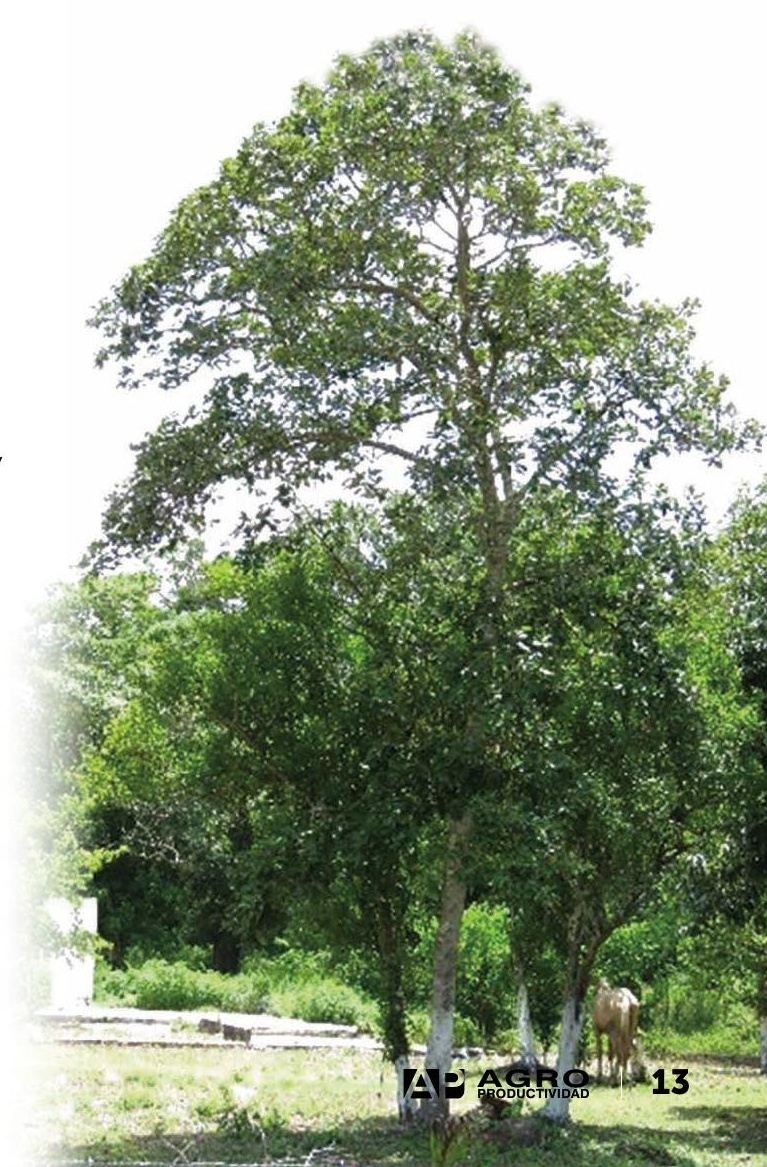


tree growth to climate variability for each species could be a projection of the differences in growth strategies among species. The species Couepia polyandra (Kunth) Rose (Chrysobalanaceae) is a tree known by the name of Uspí (Pennington \& Sarukhán, 2005) in the Yucatán Peninsula, Mexico; and it is the only identified species of the genus growing in Mexico (Ojasti, 2001). It is native to the country and has a neo-tropical distribution extending from Mexico to Costa Rica (Durán-Espinosa and Lorea, 2010). C. polyandra inhabits jungles, from medium subevergreen to low deciduous, preferably along river banks (Pennington \& Sarukhán, 2005; Vázquez et al., 2010), and at altitudes 0 to 600 m (Durán-Espinosa \& Lorea, 2010; Lascurain et al., 2010). It is a tree that can reach heights from 6 to $30 \mathrm{~m}$ (Figure 1) with a diameter at breast height (DBH) up to $40 \mathrm{~cm}$ (Pennington \& Sarukhán, 2005; Durán-Espinosa \& Lorea-Hernández, 2010). It has axillary, terminal and paniculate inflorescences with white flowers. The fruit is an ellipsoid drupe (up to $45 \times$ $25 \mathrm{~mm}$ ), green when immature and orange when ripe. It is important to highlight the fresh consumption of ripe fruits in the states of Veracruz, Tabasco and Yucatan (Martinez et al., 2007; Lascurain et al., 2010; Magaña, 2010; Vázquez et al., 2010; Román et al., 2016). It is worth mentioning that Ruenes-Morales et al., (2016) report Uspí as a floristic element of the Yucatan jungles, cultivated in an isolated or tolerated manner in domestic plots or backyard orchards, in addition to being considered underused because its market is just local. Given this, studies evaluating natural history data of C. polyandra are scarce. However, there are researches with other species of the Chrysobalanaceae family, among which there is the one by Knowles and Parrotta (1997) who studied the characteristics of the flowering of 160 species in the heart of the Amazon in Brazil, among them Couepia longipendula, Couepia sp., Licania heteromorpha, and L. micrantha, pointing out that tree species show an inverse relationship with rainwater, and flowering peaks occur during the first months of the dry season (July-October). Fruiting trends closely follow annual rainfall patterns, with a peak in the number of fruiting species occurring during the wet season (December-May).

Ruíz and Alencar (1999) who documented the foliation, flowering and fruiting of five species (Couepia longipendula, C. robusta, Licania heteromorpha, L. longistyla and L. octandra) in the middle of the Brazilian Amazon rainforest, thus establishing that some climatic factors are involved with the interaction factors of the biotope environment and physiological factors causing long periods of intervals in flowering and fruiting. Ortiz et al. (2016) relate eleven species by their responses to environmental-abiotic variables in two ways: with a stronger correlation to water variables and the second, where thermic variables showed greater influence on growth. Licania intrapetiolaris was the species exhibiting the second response. Ríos-García et al. (2017) provide data on the durability of flowering and fruiting events, related to temperature and precipitation of Licania arborea in Chiapas, Mexico. They stated that flower production in the tree is influenced by a positive mean relationship with temperature, highlighting that both variables are dependent. The present study describes the different reproductive phenological stages since flower buds production, through flowering and fruiting

to the formation of mature fruits and foliation of 21 Couepia polyandra trees grown in domestic plots and orchards, and associated with mango trees (Mangifera indica) in Palizada,

Campeche, Mexico, during April 2016 to October 2017, correlating allometric data of tree height diameter at breast height (in Spanish, DAP) crown diameter, and reproductive phenology to precipitation data.

\section{MATERIALS AND METHODS}

\section{Description of the study area}

Field study was conducted in Palizada municipality, southwest of Campeche state (Figure 2). Elevations range from 0 to $40 \mathrm{~m}$ above sea level (Mendoza-Vega \& Kú-Quej, 2010). Original vegetation according to Miranda and Hernández X. (1963) is medium sub-evergreen forest. The predominant climate is warm humid with abundant rains 
in summer $A(m)$, and average annual temperature of 26.7 to $28^{\circ} \mathrm{C}$ (INEGI, 2015). Average annual precipitation is $1200-2000 \mathrm{~mm}$ with a rainy period from May to October; the highest precipitation occurs in the months of July, August and September (García, 1981; INEGl, 2011). Dry season is relatively more pronounced; it begins in January and ends in April, and the driest month is March (García, 1981).

A mid-summer drought occurs during July to August (Gío-Argáez, 1996; Mendoza-Vega \& Kú-Quej, 2010). The Palizada river and its tributaries, the Viejo river and the Limonar river, run across this municipality. The hydrological potential of this municipality is constituted by the Palizada River. According to the FAO / UNESCO classification, the soil types are Vertisols, Gleysol, Luvisols; and Leptosols in a minimal proportion (BautistaZuñiga et al. 2010).

\section{Tree structure}

Records were made monthly and were carried out during April to December, and from January to October, of 21 individuals of $C$. polyandra marked for identification in each of the visits that were made to plots and orchards with associated mango trees (Mangifera indica). Each tree had a descriptive card (passport data) which included name of the tree, tree number, location defined by GPS, initial date, diameter at breast height $(\mathrm{DBH})$ measured at $1.30 \mathrm{~m}$ height using a caliper, tree height recorded with a SUUNTO clinometer, and crown width of each individual (Table 1); also, the subsequent data collection on reproductive phenology and foliage description. Leaves were cut into branches and flowers collected to be deposited in herbaria (CEDESU-UAC and UADY) and fruits were recollected for further germination study (Mejenes-Lopez et al., 2019).

\section{Flower buds, flowering and fruiting}

Observations were made directly on a monthly basis, with a photographic camera (Canon SX60HS 65, using Zoom); recording in the individual formats, observation date and changes according to reproductive phenological stage of flower buds setting, flowering and fruiting, recorded in percentage with the method described by Fournier (1974), modified by Newstrom et al. (1994) and PinedaHerrera et al. (2012), where a scale is used according to the percentage of presence, in events that range from 0 to 4 , as follows: total absence of the event $=0,1-25 \%=$ $1,26-50 \%=2,51-75 \%=3$ and $76-100 \%=4$.

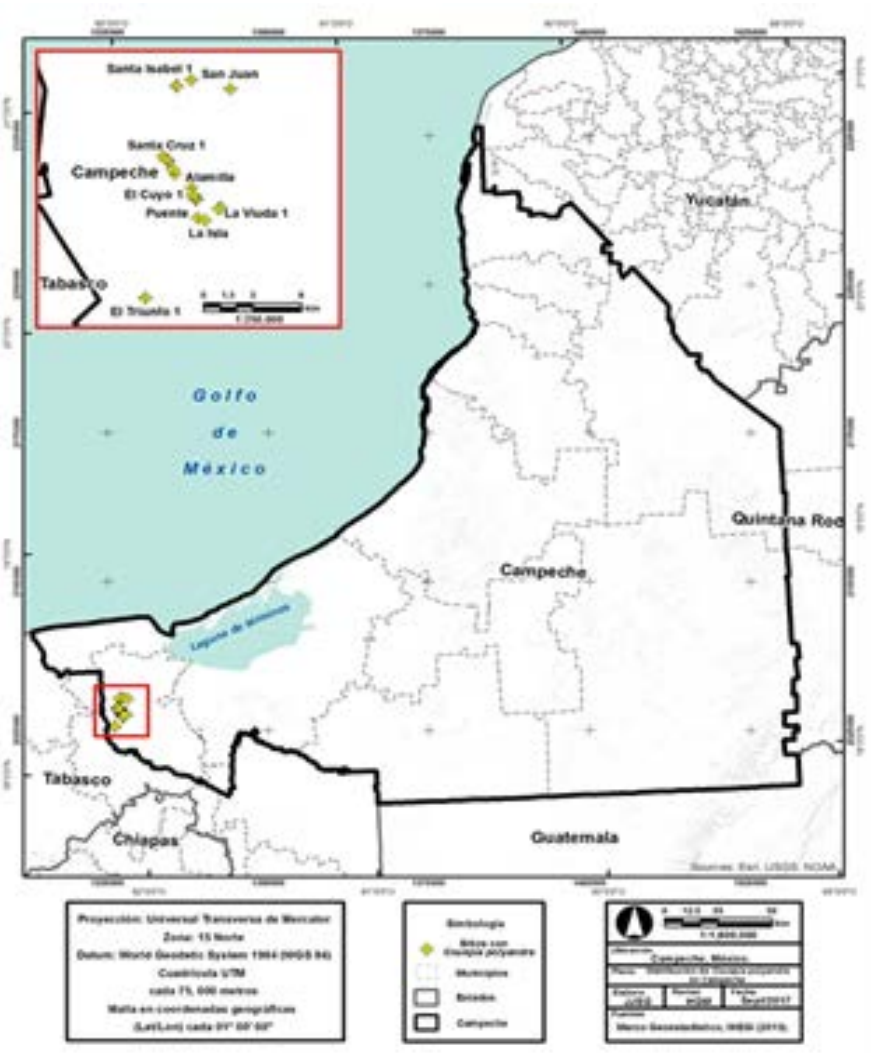

Figure 2. Location of individuals of Couepia polyandra (Kunth) Rose in the municipality of Palizada, Campeche, Mexico.

\section{Foliage}

For this variable, presence of leaves was observed in each tree crown and the percentage was evaluated using the method described for reproductive phenology (Op. Cit).

\section{Statistical analysis/Correlation}

Data matrices were constructed for the correlation analysis among the variables height, DBH and crown diameter (statistical software STATISTICA V.7.1, Stat Soft, 2005); as well as for the correlation between reproductive phenological stages and monthly total precipitation (mm) (INEGl 2016, 2017). They were evaluated with comparison of Tukey means p >0.05 (Spearman) (Gotelli \& Ellison, 2004).

\section{RESULTS AND DISCUSSION}

\section{Tree structure and correlation of allometric data}

The highest tree was $21.0 \mathrm{~m}$ and the shortest, $5.75 \mathrm{~m}$ with an average height of $10.38 \mathrm{~m}$. The highest recorded DBH was $68 \mathrm{~cm}$ while the lowest was $15 \mathrm{~cm}$, with a general average of $33.17 \mathrm{~cm}$. Regarding crown diameter, the smallest was $4.6 \mathrm{~m}$ and the largest was $34.45 \mathrm{~m}$, average width was $9.37 \mathrm{~m}$. A significant correlation was found between tree height and DAP $(r=0.91, p<0.05)$; 


\begin{tabular}{|c|c|c|c|c|c|}
\hline Number & Locality & Coordinates (UTM) & $\begin{array}{l}\text { Height } \\
\text { (m) }\end{array}$ & $\begin{array}{c}\text { Diameter } \\
\text { at breast } \\
\text { height } \\
\text { DBH } \\
(\mathrm{cm})\end{array}$ & $\begin{array}{c}\text { Cup } \\
\text { diameter } \\
\left(\mathrm{m}^{2}\right)\end{array}$ \\
\hline 1 & San Isidro, puente de palizada & $2018752.275-596421.464$ & 5.75 & 54 & 10.22 \\
\hline 2 & Rivera Santa Isabel, Km.13. Highway Palizada Santa Isabel, S/N. & $2027940.549-596610.364$ & 10.92 & 21 & 5.1 \\
\hline 3 & Rivera Santa Cruz, Highway Palizada-Santa Isabel & $2023030.86-594556.25$ & 10.80 & 68 & 10.79 \\
\hline 4 & Rivera Alamilla, Highway Santa Isabel & $2020773.432-596152.973$ & 7.90 & 60 & 9.62 \\
\hline 5 & Rivera Santa Isabel & $2027603.843-595660.992$ & 1.05 & 16 & 7.6 \\
\hline 6 & Rivera Santa Isabel & $2027607.034-595684.459$ & 11.79 & 30 & 7.4 \\
\hline 7 & Rivera El Cuyo. Domicilio Conocido, Km. 1.3 & $2019984.784-596412.378$ & 13.45 & 28 & 34.45 \\
\hline 8 & Rivera El Cuyo. Domicilio Conocido & $2020021.316-596341.719$ & 9.58 & 27.5 & 7.8 \\
\hline 9 & Rivera El Cuyo, Km. 2 & $2020251.296-596231.922$ & 11.69 & 27.8 & 8.89 \\
\hline 10 & Rivera El Cuyo, Km. 2.1 & $2020306.665-596240.455$ & 6.00 & 16 & 3.25 \\
\hline 11 & Rivera Santa Cruz & $2021767.603-595187.864$ & 8.00 & 21.1 & 6.56 \\
\hline 12 & Rivera Santa Cruz & 2022099.105-595095.206 & 8.77 & 22.2 & 7.5 \\
\hline 13 & Highway La Viuda & $2019355.894-597877.965$ & 2.10 & 53.5 & 8.07 \\
\hline 14 & La Isla, San Isidro & $2018572.986-596833.504$ & 9.94 & 23.1 & 10.71 \\
\hline 15 & Rivera San Juan, Highway Palizada-Santa Isabel & $2027196.272-598944.853$ & 9.12 & 15 & 4.6 \\
\hline 16 & Rivera Santa Cruz Highway Palizada-Santa Isabel & $2022642.129-594825.343$ & 14.13 & 35 & 9.58 \\
\hline 17 & Rivera Santa Cruz, Highway Palizada-Santa Isabel & $2022738.875-594747.354$ & 12.53 & 34 & 11.25 \\
\hline 18 & Rancho El Triunfo, Km 9, Highway Palizada-Jonuta & $2013650.323-592846.398$ & 10.58 & 56 & 7.75 \\
\hline 19 & Rancho El Triunfo, Km 9, Highway Palizada-Jonuta & $2013650.014-592846.106$ & 7.92 & 23 & 7.63 \\
\hline 20 & Rancho El Triunfo, Km 9, Highway Palizada-Jonuta & $2013649.705-592845.814$ & 7.45 & 24 & 9.95 \\
\hline 21 & Highway La Viuda a 1.6 km de la Parroquia San Joaquín & $2019260.914-597755.987$ & 10.25 & 41.5 & 8.12 \\
\hline
\end{tabular}

correlations for the variables Height-Crown and DAPCrown were not significant ( $p>0.05)$.

\section{Reproductive Phenology and phenological calendar}

The development of phenological events of $C$. polyandra in the study area during 18 months (20162017) presented the same pattern (Table 2). Flower buds appear from April to July, while flowering also begins in April, but its maximum representation occurs in May and June, and decreases in July and August. Fruiting develops between May and June, with the highest value in August. The vegetative phenological stage of foliation was the most notable event, since individuals maintain their foliage throughout the year. This fact qualifies this species as an evergreen tree (Pennington \& Sarukhán, 2005) despite it is a cultivated species.

\section{Phenology related to precipitation}

According to precipitation data during the study period, variations were registered each month of the sampling period, in June 2016 (223 mm) and 2017 (210 $\mathrm{mm}$ ). As well as in November 2016, the highest (289.5 $\mathrm{mm}$ ) precipitation occurred; and the lowest (345.4 $\mathrm{mm}$ ) was in September 2017. This may indicate that phenological stages of the C. polyandra species are related to precipitation. Since flower bud production, flowering and fruiting occur on these precipitation events, we suggest that those stages are favored by the season (Figure 3). While with high rainfall no presence of any phenological stage. Precipitation of $34.14 \pm$ $6.78 \mathrm{~mm}$ was recorded during the dry period, while during the rainy season, the recorded value was $204.49 \pm 23.76 \mathrm{~mm}$.

All individuals were reproductive from the minimum height of $5.75 \mathrm{~m}$. DBH has a correlation with height which define this tree species as sexually mature for producing fruits, C. polyandra resulted a species of annual reproduction. 


\begin{tabular}{|c|c|c|c|c|}
\hline & Leaves & $\begin{array}{l}\text { Flower } \\
\text { bud }\end{array}$ & Flowering & Fructification \\
\hline $\operatorname{jan}^{2017}$ & 4 & & & \\
\hline $\mathrm{feb}^{2017}$ & 4 & & & \\
\hline $\mathrm{mar}^{2017}$ & 4 & & & \\
\hline $\mathrm{apr}^{2016-2017}$ & 4 & 2 & 2 & \\
\hline may $^{2016-2017}$ & 4 & 3 & 4 & 1 \\
\hline jun 2016-2017 & 4 & 3 & 4 & 2 \\
\hline jul 2016-2017 & 4 & 2 & 4 & 3 \\
\hline $\operatorname{agu}^{2016-2017}$ & 4 & & 2 & 4 \\
\hline $\operatorname{sep}^{2016-2017}$ & 4 & & & 1 \\
\hline oct $^{2016-2017}$ & 4 & & & \\
\hline$n^{2} v^{2016}$ & 4 & & & \\
\hline $\operatorname{dec}^{2016}$ & 4 & & & \\
\hline
\end{tabular}

Escale: 0 (0\%), 1 (1-25\%), 2 (26-50\%), 3 (51-75\%), 4 (76-100\%).

Through phenological analysis, it is recognized that the species has a suitable period for the collection of seasonal fruits in the months of June, July and August; when fruits show maturity and are recollected from the ground for self-consumption, that is the moment of peak maturity (Chi-Saénz, 2016; Ruenes Morales et al., 2016; Mejenes-López et al., 2019).

This study area has well-defined climatic seasons (dry and rainy); its influence was recording in the expression of flower buds, flowering itself, and fruiting of C. polyandrous that occurs in early June. This suggests that the water factor can be a strong trigger to the formation of inflorescence and fruit, as it was indicated by Rios-Garcia et al. (2017) for L. arborea, pointing out that flowering and fruiting events, as well as their relationship with temperature and precipitation, are dependent variables; and temperature registered a positive average relationship with the production of flowers in the tree.

\section{CONCLUSIONS}

C. polyandra species shows a pattern in reproductive phenological stages, showing a duration of flowering (April to August) and fruiting (May to September), five months for both events. Phenological traits are referred to the period and site of study; therefore, it is recommended to continue studying wild populations of the Pacific slope, in order to build the foundation needed to clarify the complex physiological processes and their relation to phenology.

\section{REFERENCES}

Bautista-Zuñiga, F., Palacio-Aponte A.G., Mendoza-Vega J., Kú-Quej V.M., Pool-Novelo L. \& Cantarell-Jiménez W. (2010). Suelos. Pp. 20-27, en: La Biodiversidad en Campeche: Estudio de Estado. Comisión Nacional para el Conocimiento y Uso de la Biodiversidad (CONABIO), Gobierno del Estado de Campeche, Universidad Autónoma de Campeche, El Colegio de la Frontera Sur. México. 730 p

Chi-Saénz R. G (2016). Distribución poblacional y etnobotánica del fruto de Usbid o Uspid (Couepia polyandra (Kunth) Rose, Chrysobalanaceae) en el Estado de Campeche, México. Reporte Final de Residencia Profesional. Licenciatura en Biología. ITCHINÁ, TecNM. Chiná, Campeche, Camp.

Durán-Espinosa C. \& Lorea Hernández F. G. (2010). Chrysobalanaceae. Flora del Bajio. Instituto de Ecología A. C. Xalapa, Veracruz, México. Fascículo 150, 39 págs.

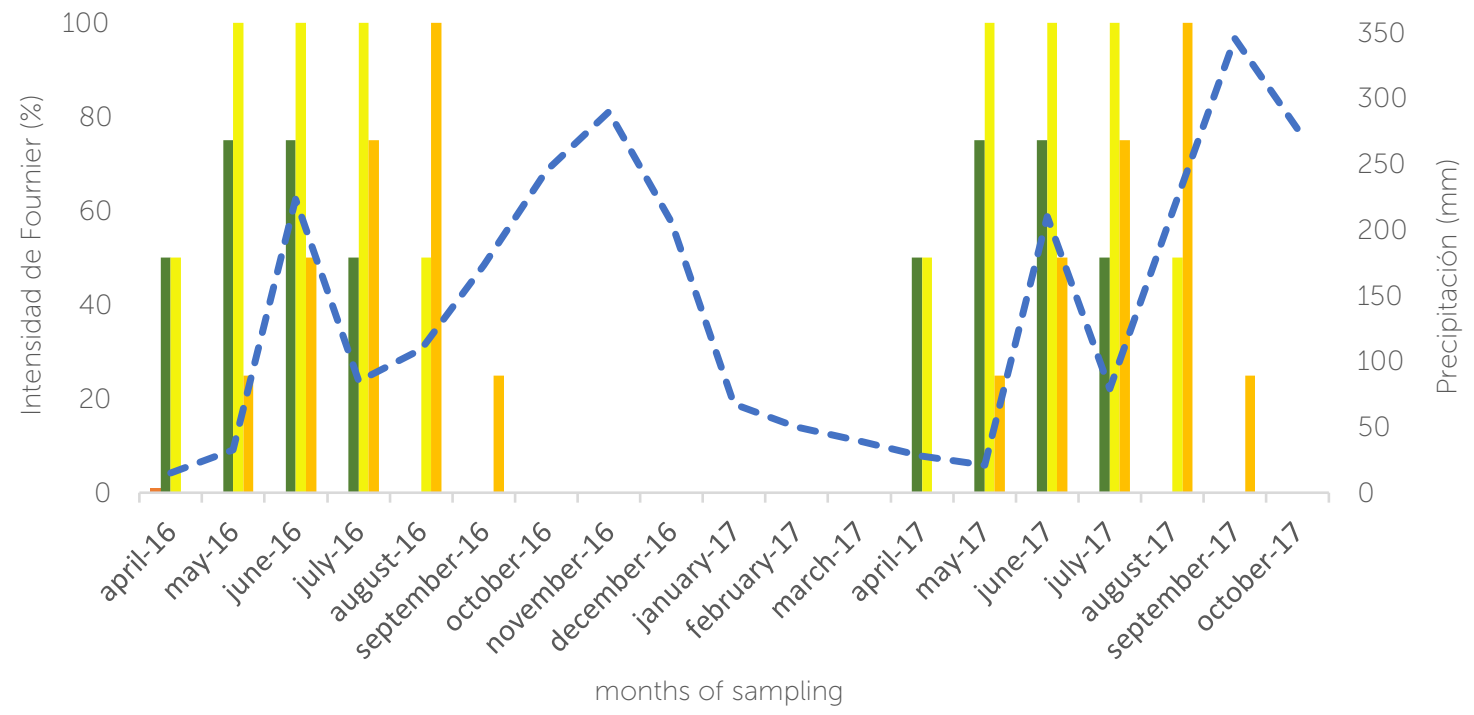

FLOWER BUD $\quad$ FLOWERING 
Fournier, L. (1974). Un método cuantitativo para la medición de características fenológicas de árboles. Turrialba 24(4): 422-423.

García E. (1981). Modificaciones al sistema de clasificación de Köppen para adaptarlo a las condiciones de la República Mexicana. Instituto de Geografía, Universidad Nacional Autónoma de México. Serie libros No. 6. México, DF. 98 p. https://www.academia.edu/12911044/Modificaciones_ al_sistema_de_clasificaci\%C3\%B3n_clim\%C3\%A1tica_ de_K\%C3\%B6ppen_para_adaptarlo_a_las_condiciones_ de_la_Rep\%C3\%BAblica_Mexicana_2004_._Enriqueta_ Garc\%C3\%ADa

Gío-Argáez F.R. (1996). Campeche y sus recursos naturales. Revista Mexicana de Historia Natural, A.C. Vol. Esp. 247 p

Gotelli, N. J., \& Ellison, A. M. (2004). Primer of ecological statistics. Sinauer Associates Publishers.

INEGI. (2011). Anuario de estadísticas por entidad federativa 2011. Instituto Nacional de Estadística y Geografía. Aguascalientes, Ags, México. (http.www.inegi.gob.mx)

INEGI. (2015). Anuario estadístico y geográfico de Campeche. Instituto Nacional de Estadística y Geografía. Aguascalientes, Ags, México. 382 págs. (http.www.inegi.gob.mx)

INEGI. 2016. Anuario estadístico y geográfico de Campeche 2016. Instituto Nacional de Estadística y Geografía. Aguascalientes Aguascalientes, México. 405 p.

INEGI.2017. Anuario estadístico y geográfico de Campeche 2017 Instituto Nacional de Estadística y Geografía. Aguascalientes, Aguascalientes, México.399 p.

Knowles, O. H. \& Parrotta J. A. (1997). Phenological observations and tree seed characteristics in an equatorial moist forest at Trombetas, Para State, Brazil, in Phenology in Seasonal Climates I, edited by H. Leith, and M. D. Schwartz, pp. 67-84,

Lascurain M., Avendaño S., del Amo S. \& Niembro A. (2010). Guía de frutos silvestres comestibles en Veracruz. Fondo Sectorial para la Investigación, el Desarrollo y la Innovación Tecnológica Forestal, CONAFOR-CONACYT, México. 74 pp

Magaña A. M. A. (2010). Vegetación y Flora del Municipio de Paraíso Universidad Juárez Autónoma de Tabasco. Villahermosa Tabasco. 163 págs. (http://www.archivos.ujat.mx/2011/ difusion/libros/29.pdf)

Martínez M. A., Evangelista V., Basurto F., Mendoza M. \& Cruz-Rivas A. (2007). Flora útil de la sierra norte de Puebla. Revista Mexicana de Biodiversidad 78: 15-40Naranjo Morán J. y E. Chica Martínez. (2017). Germinación y crecimiento inicial de plántulas de Guaij (Conepia subcordata) bajo condiciones de vivero. Bionatura. 2(2): 296-298. DOI. 10.21931/RB/2017.02.02.4 http://www revistabionatura.com

Mejenes-López, S.M.A., Chi-Sáenz G.R., Flota-Bañuelos C., CandelariaMartínez B. \& Chiquini-Medina R.A. (2019). Germinación y características de plántulas de Uspí (Couepia polyandra: Chrysobalanaceae) en condiciones de vivero rústico en Campeche, México. Núm. 48:111-120 México. Julio 2019 DOI: 10.18387/Polibotánica.48.9

Mendoza V. J. \& Kú Quej V. M. (2010). Clima. Pp. 16-19, In VillalobosZapata, G. J., y J. Mendoza Vega (Coord.). La Biodiversidad en Campeche: Estudio de Estado. Comisión Nacional para el Conocimiento y Uso de la Biodiversidad (CONABIO), Gobierno del Estado de Campeche, Universidad Autónoma de Campeche, El Colegio de la Frontera Sur. México. 730 p
Miranda, F., \& Hernández, X. E. (1963). Fisiografía y vegetación. Las zonas áridas del centro y noreste de México. IMRNR. México, DF. 27p

Newstrom L. E., Frankie G. W., \& Baker H. G. (1994). A new classification for plant phenology based on flowering patterns in lowland tropical rain forest trees at La Selva, Costa Rica. Biotropica, 141-159.

Ojasti, J. (2001). Estudio sobre el estado actual de Las especies exóticas. Estudio nacional. In Estrategia regional de biodiversidad para los países del trópico andino. Caracas, Venezuela.

Ortiz J., Hernández L. \& Schöngart J. (2016). Incremento diamétrico mensual de especies arbóreas relacionado con variables ambientales y fenología en un bosque nublado al sudeste de Venezuela. Acta Bot. Venez.39 (1): 1-36.

Pennington T. D. \& Sarukhán, J. (2005). Árboles tropicales de México. UNAM y Fondo de Cultura Económica. México, D. F. 521.

Pineda-Herrera E., Valdez-Hernández J. I., Pérez-Olvera C. de la Paz \&Dávalos-Sotelo R. (2012). Fenología, incremento en diámetro y periodicidad de anillos de crecimiento de Enterolobium cyclocarpum (Jacq.) Griseb (Leguminosae) en Costa Grande, Guerrero, México. Polibotánica, núm. 43: Disponible en: http:// www.redalyc.org/articulo.oa?id= 62150424009

Porter Bolland, L. (2003). La apicultura y el paisaje maya. Estudio sobre la fenología de floración de las especies melíferas y su relación con el ciclo apícola en La Montaña, Campeche, México. Mexican Studies, 19(2), 303-330.

Ríos-García C. A., Orantes-García C., Verdugo-Valdez A. G., SánchezCortés M. S., \& Farrera-Sarmiento O. (2017). Estudio fenológico de Licania arborea Seem (Chrysobalanaceae) en Jiquipilas, Chiapas; México. Agroproductividad, 10(8).

Román Miranda M. L., Mora Santacruz A., \& González Cueva G. A. (2016). Sistemas agroforestales con especies de importancia maderable y no maderable, en el trópico seco de México. Avances en Investigación Agropecuaria, 20(2).

Rozendal D. \& Zuidema P. (2011). Dendroecology in the tropics: review. Trees 25: 3-16.

Ruenes Morales M. del R., Montañez Escalante P. I., Ancona J. J. \& Ek Rodríguez, I. L. (2016). Los frutales abandonados y subutilizados en la Península de Yucatán. Universidad Autónoma de Yucatán, Red temática sobre el Patrimon. Red temática sobre el Patrimonio Biocultural de México.

Ruíz J. E. A \& Alencar J. C. (1999) Interpretacao fenológica de cinco espécies de Chrysobalanaceae na reserva florestal Adolpho Ducke, Manaus, Amazonas, Brasil. Acta Amazonica 29 (2):223-242

Salinas-Peba L. \& Parra-Tabla V. (2007). Phenology and pollination of Manilkara zapota in forest and homegardens. Forest Ecology and Management 248(3):136-142 DOI: 10.1016/j. foreco.2007.04.046

StatSoft; Inc. (2005). STATISTICA. Retrieved from www.statsoft.com

Valdez-Hernández M., Andrade J.L., Jackson P.C. \& Rebolledo-Vieyra M. (2010). Phenology of five tree species of a tropical dry forest in Yucatan, Mexico: effects of environmental and physiological factors. Plant and soil 329:155-171.

Vázquez Torres M., Campos Jiménez J., Armenta Montero S. \& Carvajal Hernández C. I. (2010). Árboles de la región de Los Tuxtlas. Gobierno del Estado de Veracruz, Secretaría de Educación del Estado de Veracruz. Xalapa, Veracruz. 424 págs. ISBN 978-60733-0007-0 